\title{
Leiomyosarcoma of the great saphenous vein
}

\section{Leiomiossarcoma de veia safena magna}

\author{
Alexandre Campos Moraes Amatoํㅜ, Ana Júlia de Deus Silva', Ricardo Virgínio dos Santos, \\ Salvador José de Toledo Arruda Amato²
}

\begin{abstract}
A 56-year-old male patient presented with a complaint of two painful, hard, palpable nodules in the right lower limb. A Doppler ultrasound scan revealed the presence of nodules, likely to be neoplastic. Computed angiography showed two solid hypervascular nodules in the right great saphenous vein, fed by branches of the posterior tibial artery. Embolization of the nodules using surgical cyanoacrylate was performed, followed by an excisional biopsy. Anatomical pathology and immunohistochemical analysis identified the nodule as a high-grade leiomyosarcoma, characterized by ten mitotic figures per ten high-power fields, necrosis and cell pleomorphism. Immunohistochemical analysis results were positive for caldesmon and desmin labeling. A second surgical procedure was performed to enlarge the free margins.
\end{abstract}

Keywords: neoplasms; vascular tissue neoplasms; blood vessels.

\section{Resumo}

Paciente do sexo masculino, 56 anos, com queixa de dois nódulos palpáveis, dolorosos e rígidos, em membro inferior direito. O eco-Doppler colorido evidenciou nódulos de provável natureza neoplásica na veia safena magna direita distal, com fluxo de baixa velocidade no seu interior. A angiotomografia evidenciou dois nódulos sólidos hipervascularizados no trajeto da veia safena magna direita, possuindo ramos nutridores provenientes da artéria tibial posterior. Para realizar a biópsia excisional dos nódulos, optou-se inicialmente pela embolização do tumor com cola cirúrgica de cianoacrilato, devido à sua alta vascularização. Os exames anatomopatológico e imuno-histoquímico evidenciaram leiomiossarcoma de alto grau, com dez mitoses por dez campos de grande aumento, necrose tumoral e pleomorfismo celular. A imuno-histoquímica demonstrou positividade para os marcadores Caldesmon (anticorpo hCD) e Desmina (anticorpo D33). O paciente realizou uma nova cirurgia para ampliação de margens comprometidas e está em acompanhamento clínico com a Oncologia.

Palavras-chave: neoplasias; neoplasias de tecido vascular; vasos sanguíneos. 


\section{INTRODUCTION}

Leiomyosarcomas of the vascular system are extremely rare tumors, accounting for approximately $2 \%$ of this type of neoplasm, ${ }^{1}$ and most often affecting the gastrointestinal tract or the uterus. ${ }^{2}$ Leiomyosarcomas of major blood vessels account for $0.95 \%$ of all sarcomas and the inferior vena cava is the most common site for these cases. This type of sarcoma originates in smooth muscle cells and, despite its rarity, leiomyosarcoma is the most frequent type of primary malignant vascular tumor. Leiomyosarcoma is five times more frequent in the veins than in the arteries, ${ }^{1-4}$ and this type of sarcoma affects men and women equally, with peak incidence from 55 to 61 years of age. ${ }^{4}$

\section{CASE REPORT}

A 56-year-old male patient presented with a complaint of two painful, hard, palpable nodules in the right lower limb. A Doppler ultrasound scan revealed the presence of nodules (most likely neoplastic) with both intraluminal and extraluminal components and reduced blood flow in the distal portion of the right great saphenous vein (Figure 1). Computed angiography showed two solid hypervascular nodules in the right great saphenous vein, measuring $1.7 \times 0.8 \mathrm{~cm}$ and $1.9 \times$ $0.8 \mathrm{~cm}$ and fed by branches of the posterior tibial artery (Figure 2). In view of the significant vascularization of the tumors (Figure 3, left), it was decided that the nodules should be embolized (Figure 3, right) prior to the excisional biopsy using cyanoacrylate surgical glue $\left(\right.$ Glubran $\left.^{\circledR}\right)$ combined with iodinated poppy seed oil (Lipiodol $\left.{ }^{\circledR}\right)$. The tumors were excised 4 days after embolization and the specimen was sent for anatomical pathology and immunohistochemical analysis, which identified the nodule as a high-grade leiomyosarcoma (Figure 4), characterized by ten mitotic figures per ten high-power fields, necrosis and cell pleomorphism. Immunohistochemical analysis results were positive for caldesmon (anti-hCD antibody) and desmin (antibody clone D33) labeling. A second surgical procedure was performed to enlarge the free margins. The patient is currently being followed up by the oncology department. The patient authorized publication of his case and signed a consent form.

\section{DISCUSSION}

Because the disease is malignant, fast-evolving and demands wide surgical margins, ${ }^{5}$ halting the progression of leiomyosarcoma depends on early

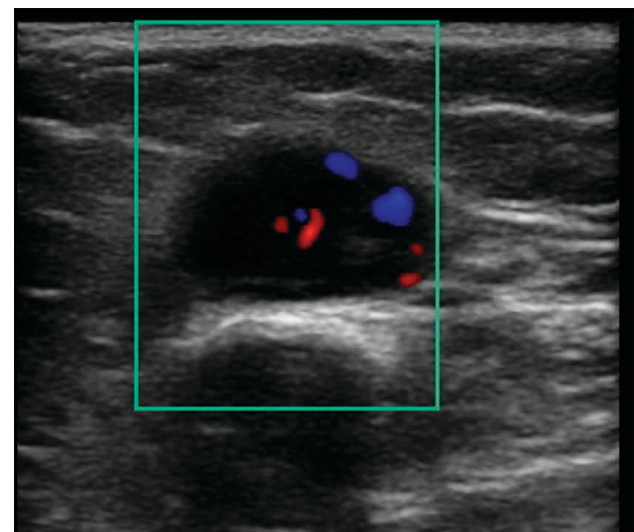

Figure 1. Neoplastic and vascularized nodules shown on Doppler ultrasound.

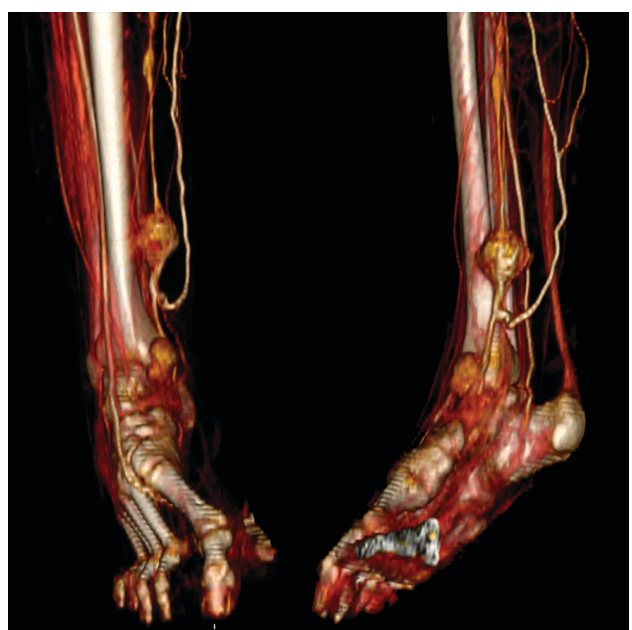

Figure 2. Three-dimensional angiotomography reconstruction revealed the presence of two solid hypervascular nodules in the right great saphenous vein, fed by branches of the posterior tibial artery.

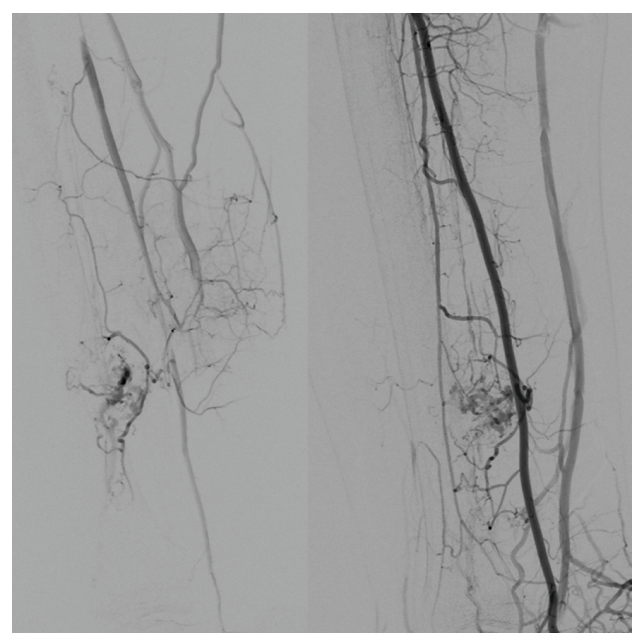

Figure 3. Left: arteriography of hypervascular nodule. Right: final result after embolization. 


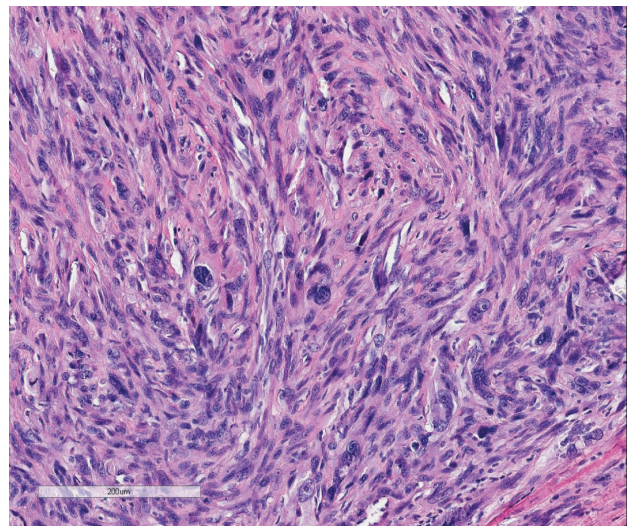

Figure 4. Microscopy of vein wall, showing high-grade leiomyosarcoma 2 (FNCLCCC) and high grade TNM, tumor necrosis with ischemic pattern, marked cellular pleomorphism and 10 mitoses per 10 high power fields.

diagnosis, high degree of clinical suspicion and effective intervention. ${ }^{3}$

Amputation should be considered where lesions are located below the knee, especially in cases with high-grade sarcoma, ${ }^{6}$ as well as in patients with bone or nerve involvement. ${ }^{7}$ When the great saphenous vein is affected, as in the case described here, surgical treatment increases survival rates by $80-90 \%{ }^{8}$ Metastases are present in $44 \%$ of cases at the time of diagnosis ${ }^{9}$ and in $60 \%$ by the time of surgery. ${ }^{8}$ Diagnosis is quite difficult, as the case reported here illustrates, since this patient saw several specialists before a diagnosis of leiomyosarcoma of the great saphenous vein was established. The diagnostic difficulty is due to the great similarity of the clinical examination findings for this type of tumor and for its differential diagnoses of lipoma, epithelioid hemangioendothelioma and angiosarcoma. ${ }^{4}$

\section{REFERENCES}

1. Song KY, Jang YW, Kim MK, Lee GY, Sung RH. Leiomyosarcoma arising in the great saphenous vein: a case report. J Korean Med Sci. 1991;6(4):372-5. http://dx.doi.org/10.3346/jkms.1991.6.4.372. PMid:1844647

2. Fujimoto $S$, Mizuno R, Saito $Y$, Nakamura S. Clinical application of wave intensity for the treatment of essential hypertension. Heart Vessels. 2004;19(1):19-22. http://dx.doi.org/10.1007/s00380-0030725-9. PMid:14685750

3. Marle AG, Bronkhorst MW, Brouwers MA. Leiomyosarcoma of the great saphenous vein: a case report and review of the literature. Sarcoma. 2004;8(4):135-9. http://dx.doi.org/10.1155/ S1357714X04000234. PMid:18521408

4. Bibbo C, Schroeder M. Review of vascular leiomyosarcoma and report of a case localized to the greater saphenous vein of the ankle. J Foot Ankle Surg. 2011;50(3):329-35. http://dx.doi.org/10.1053/j. jfas.2011.01.002. PMid:21435912

5. Cormier JN, Pollock RE. Soft tissue sarcomas. CA Cancer J Clin. 2004;54(2):94-109. http://dx.doi.org/10.3322/canjclin.54.2.94 PMid:15061599

6. Banks AS, Downey MS, Martin DE, Miller SJ. Tumors: part 2, soft tissue masses. In: Doeney MS, Gredlein CM, editors. McGkamry`s Comprehensive Textbook of Foot and Ankle Surgery. 3rd ed. Philadelphia: Lippincott Williams \& Wilkins; 2001. p. 1339-1368

7. Reix T, Sevestre H, Sevestri-Pietri M-A, Szychta P, Pietri J. Primary malignant tumors of the venous system in the lower extremities. Ann Vasc Surg. 1998;12(6):589-96. http://dx.doi.org/10.1007/ s100169900205. PMid:9841691

8. Humphrey M, Neff J, Lin F, Krishnan L. Leiomyosarcoma of the saphenous vein: a case report and review of the literature. J Bone Joint Surg Am. 1987;69(2):282-6. PMid:3805093.

9. Abed R, Abudu A, Grimer RJ, Tillman RM, Carter SR, Jeys L. Leiomyosarcomas of vascular origin in the extremity. Sarcoma. 2009;2009:385164. http://dx.doi.org/10.1155/2009/385164. PMid:19587823

Correspondence Alexandre Campos Moraes Amato Av. Brasil, n. 2283 - Jardim America CEP 01431-001 - São Paulo (SP), Brazi E-mail:dr.alexandre@amato.com.br

Author information

ACMA - professor of Vascular Surgery at Universidade de Santo

Amaro (UNISA), São Paulo, SP, Brazil; a member with Sociedade Brasileira de Angiologia e Cirurgia Vascular; Board certified in Vascular and Endovascular Surgery from Sociedade Brasileira de Angiologia e Cirurgia Vascular; and Board-certified in Vascular Doppler Ultrasound from pelo Colégio Brasileiro de Radiologia. AJDS - medical student at Universidade de Santo Amaro (UNISA). RVS - professor of Vascular Surgery at Universidade de Santo Amaro (UNISA)

SJTAA - chief of the Vascular Surgery team at Amato, Instituto de Medicina Avançada.

Author contributions Conception and design: ACMA, SJTAA Analysis and interpretation: ACMA, RVS, STTAA Data collection: ACMA, SJTAA

Writing the article: ACMA, AJDS

Critical revision of the article: ACMA, SJTAA Final approval of the article*: ACMA, AJDS, RVS, SJTAA Statistical analysis: N/A Overall responsibility: ACMA

*All authors have read and approved of the final version of the article submitted to I Vasc Bras. 